\title{
図形科学教育における図形解析学入の試み -地理情報システムを利用した教育内容と学生の評価-
}

\author{
鈴木 広隆 \\ 大阪市立大学大学院工学研究科都市系専攻
}

要旨： 図学は図法幾何学に端を発し、投影法の理解とその作図技術の習得を目的としていたが、コン ピュータ技術の発達によりコンピュータを用いた図形処理が導入され、また図形解析なども含めて図形 科学と称されるようになった。しかし、コンピュータグラフィクスについては数多くの大学の図形科学 教育のカリキュラムに既に取り入れられているものの、図形解析についてはほとんど取り入れられてい るケースが少ない。これは、伝統的な図法幾何学の教育内容を一部割愛してコンピュータグラフィクス を取り入れているケースが多いため、時間的に図形解析を導入する余裕がないことも十分考えられるが、 一般的な図形を対象として角度や長さを求めてそれを解析する作業は非常に煩雑であり、費やした時間 に見合った成果が得られないと考えられている側面も大きい。大阪市立大学の図形科学教育では、地理・ 空間解析に用いられている地理情報システムの利用により、短期間での図形解析技術の習得を試みてい る。本論文では、その教育内容と学生の評価結果について報告を行う。

キーワード : 図形科学、教育、図形解析、全学提供科目、授業評価

\section{1.はじめに}

図形科学教育は、Gaspard Monge によって体系 付けられた図法幾何学に端を発するものであり、 現在でも多くの大学において理数系学生への教養 科目として提供されている。旧来、図学とも称さ れた図法幾何学は、投影法の理解とその作図技術 の習得を目的としていたが、1960 年代のコンピュ 一夕技術の発達によりコンピュータを用いた図形 処理が導入され、現在に至るまでコンピュータ導 入の意義についての議論は続けられているものの、 図法幾何学、コンピュータグラフィクス(以下、 CG)、図形解析等幅広い範囲を含めて図形科学之 呼ぶことが一般的になっている(例えば、日本図学 会編、1980)。しかし、CG については数多くの大 学の図形科学(もしくは図学)教育のカリキュラム に既に取り入れられているものの、図形解析につ いてはほとんど取り入れられているケースが見ら れない。これは、伝統的な図法幾何学の教育内容 を一部割愛して CG を取り入れているケースが多 いため、時間的に図形解析を導入する余裕がない
ことも十分考えられるが、一般的な図形を対象と して角度や長さを求めそれを解析する作業は非常 に煩雑であり、費やした時間に見合った成果が得 られないと考えられている側面も大きい。

大阪市立大学では、図形科学を単なる図形の描 き方ではなく、高度情報化社会において適切な図 を用いてコミュニケーションを行うためのスキル を習得する場であると位置づけ、投影法の理解と 手書き作図法の習得(図形科学 I ) と、光・色の物 理的挙動・心理的効果と CG によるデザイン(図形 科学 II)のための講義・演習を提供してきた(鈴 木・三木、2002)。しかし、適切な図表現を行うた めのスキルを身に付けるためには図形解析のセン スが不可欠であると考え、2003 年度 4 月より図形 科学教育のための学生用端末に地理情報システム (以下、GIS)を導入し、前述の問題点を克服して図 形科学教育に図形解析を組み込むことを試みた。 以下、そのカリキュラムの内容と授業評価の結果 について述べる。 
2. カリキュラムの概要

\subsection{GIS による図形解析の位置づけ}

表 1 にカリキュラムの概要を示す。表の通り、 投影法の理解と作図法の習得に割り当てる時間の 割愛に限りがあるため、GIS による図形解析に割 り当てることが出来た時間は 3 コマ(270 分)のみ であった。この短い時間で GIS の理念や操作方法 の全容を理解させることは不可能であり、またそ れは本科目の趣旨とも異なるため、講義・演習の 中では GIS の学習を主たる目的とはせず、図形を 分析するためのツールと位置づけた。そして、操 作の過程で現れる GIS の基本操作方法を中心に説 明を行い、結果的に GIS の機能について簡単に学 習したことになるような進め方とした。

\section{2 履修者}

本科目は、必修科目として工学部建築学科 1 回 生、同環境都市工学科 1 回生、生活科学部居住環 境学科 1 回生、選択科目として工学部土木工学科 1 回生、同物理工学科 1 回生、同情報工学科 2 回 生を対象として開講しており、週 3 回に分けて行 われる。2003 年度前期の履修者数は以下の通りで ある。

工学部建築学科 31 名、同環境都市工学科 29 名、 同土木工学科 34 名、同物理工学科 17 名、

同情報工学科 19 名、生活科学部居住環境学科 47 名、 理学部物理学科 1 名 計 178 名

\section{3 図形科学教育を行う演習室の設備}

80 台の DOS/V 互換ノートパソコンに、GIS ア プリケーション(SIS Map Modeller Ver6.0、(株)イン フォマティクス) を導入した。端末管理アプリケ ーション(Wingnet、(株)コンピュータウィング)に より、学生の出欠管理、端末の稼動状況のチェッ ク、教員用端末の画像の配信、教材の配布回収等 を行うことができる。

図形科学 I における図形解析の演習では、時間 的な余裕がなかったため、すべての演習において 教員側である程度作りこんだ教材を配布し、演習 時間の終わりに回収する方法をとった。これらの 設備を用いた講義・演習の様子を図 1 に示す。
表 12003 年度 図形科学 |のスケジュールと内容

\begin{tabular}{|c|c|}
\hline & 内容 \\
\hline $\begin{array}{l}\text { (1)イントロダ } \\
\text { クション-線の } \\
\text { 練習 }\end{array}$ & $\begin{array}{l}\text { 样々な投影法の分類、 } \\
\text { [課題]強い線と弱線の書き分け }\end{array}$ \\
\hline $\begin{array}{l}\text { (2) 平行投影 - } \\
\text { 正投影法 }\end{array}$ & $\begin{array}{l}\text { 第三角法、第一角法 } \\
\text { [課題]等測投影で与えられた図形を正投影で表 } \\
\text { 現する }\end{array}$ \\
\hline $\begin{array}{l}\text { (3)図形の分析 } \\
\text { 評価-GIS イン } \\
\text { トロダクショ } \\
\text { ン }\end{array}$ & $\begin{array}{l}\text { 地理情報システムの概要、応用例、取り扱うデ } \\
\text { ータの紹介 } \\
\text { [課題]住宅地図の表示非表示切り替え、払大縮 } \\
\text { 小、表示位置切り替え }\end{array}$ \\
\hline $\begin{array}{l}\text { (4)図形の分析 } \\
\text { 評価-形の複雑 } \\
\text { さを測る }\end{array}$ & $\begin{array}{l}\text { 周長と面積を利用した図形の複雑さの評価 } \\
\text { [課題]基本図形·行政界を用いた円形度の評価、 } \\
\text { 主題図の作成 }\end{array}$ \\
\hline $\begin{array}{l}\text { (5) 図形の分 } \\
\text { 析評価-点の分 }\end{array}$ & $\begin{array}{l}\text { ボロノイ分割による点の分布の評価、最短経路 } \\
\text { 検索 }\end{array}$ \\
\hline 布及び線分に & [課題]与えられた点の分布、行政界を基にした \\
\hline よるネットワ & 点の分布を用いたボロノイ図の作成と点の分 \\
\hline $\begin{array}{l}\text { ークの特性を } \\
\text { 測る }\end{array}$ & $\begin{array}{l}\text { 布の評価、放射環状格子状道路網・大阪市の道 } \\
\text { 路網を用いた最短経路検索 }\end{array}$ \\
\hline $\begin{array}{l}\text { (6) 平行投影- } \\
\text { 直 軸 測 投影 } \\
\text { 法、斜軸測投 } \\
\text { 影法 }\end{array}$ & $\begin{array}{l}\text { 軸縮率、棈円角度、作図法 } \\
\text { [課題]正投影で与えられた図形を等測投影で表 } \\
\text { 現する }\end{array}$ \\
\hline $\begin{array}{l}\text { (7) 透視投 影 } \\
\text { 法-直接法 } 1\end{array}$ & $\begin{array}{l}\text { 透視投影の原理、直接法の原理と作図法 } \\
\text { [課題]正投影により与えられた簡単な図形を透 } \\
\text { 視投影で表現する }\end{array}$ \\
\hline $\begin{array}{l}\text { (8) 透視投影 } \\
\text { 法-直接法 } 2\end{array}$ & $\begin{array}{l}\text { 透視投影と平行投影において保存される情報 } \\
\text { (角度、平行関係等)の比較整理、直接法のチエ } \\
\text { ック法、視点の位直・図形の配直と実際の見え } \\
\text { 方の関係 } \\
\text { [課題]正投影により与えられたやや複雑な図形 } \\
\text { を透視投影で表現する }\end{array}$ \\
\hline $\begin{array}{l}\text { (9) 中間テス } \\
\text { ト }\end{array}$ & \\
\hline $\begin{array}{l}\text { (10) 透視投影 } \\
\text { 法-消点法 } 1\end{array}$ & $\begin{array}{l}\text { 消点法の原理と作図法、直接法に対するメリッ } \\
\text { 卜 } \\
\text { [課題]第 } 7 \text { 回と同じ }\end{array}$ \\
\hline $\begin{array}{l}\text { (11) 透視投影 } \\
\text { 法-消点法 } 2\end{array}$ & $\begin{array}{l}\text { 消点法の別の作図法、消点の数と図形の配置の } \\
\text { 関倸、消点が } 3 \text { つ以上及び傾斜直線が存在する } \\
\text { 場合の作図法 } \\
\text { [課題]第 } 8 \text { 回と同じ }\end{array}$ \\
\hline $\begin{array}{l}\text { (12) 透視投影 } \\
\text { 法-距離点法 }\end{array}$ & $\begin{array}{l}\text { 距離点法の原理と作図法 } \\
\text { [課題]第 } 7 \text { 回と同じ }\end{array}$ \\
\hline $\begin{array}{l}\text { (13) 透視投影 } \\
\text { 法-簡易消点法 }\end{array}$ & $\begin{array}{l}\text { 簡易消点法の原理と作図法、曲線の書き方 } \\
\text { [課題]第 } 8 \text { 回と同じ }\end{array}$ \\
\hline
\end{tabular}

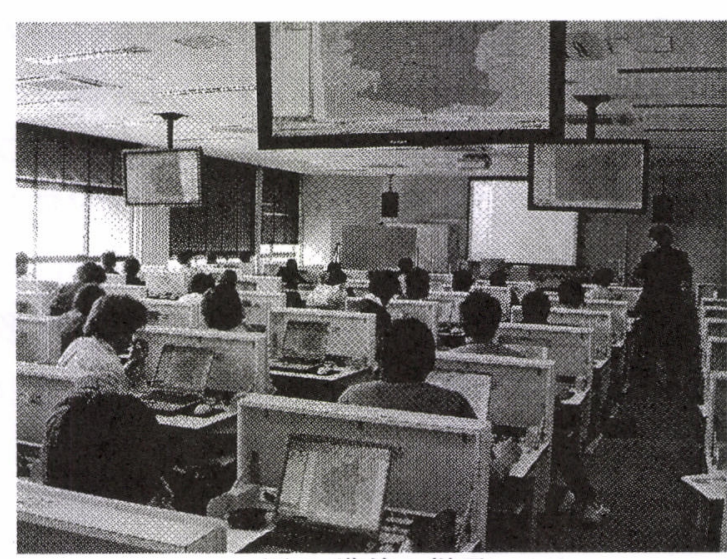

図 1 講義の様子 


\section{3. 講義と演習の内容}

GIS を用いた図形解析の 3 コマは、それぞれ 90 分のスケジュールの中で前半に講義を行い、後半 に演習を行って課題への取り組みを行った。概要 は表 1 に示した通りであるが、以下各授業の内容 の詳細を示す。

\section{$3.1 「 \mathrm{GIS}$ イントダクション」}

専門が多岐にわたる履修者を対象として GIS を 簡潔に理解させるため、GIS を表計算ソフトと関 連付け、双方とも情報の管理分析のためのアプリ ケーションであるが、GIS は数字・テキストの情 報に加えて図形・地理的な情報を扱うことが出来 る、と説明を行った。図形・空間的な情報に数字・ テキストが関連付けられている様子を述べ、属性 情報の概念を説明する。GIS を用いた分析結果の サンプルをいくつか紹介した後、ベクトルデータ とラスターデータの違い、ベクトルデータの種類 などを述べ、最後に住宅地図のデー夕を用いた演 習を行う。演習は、レイヤーの表示非表示の切り 替え、拡大縮小、表示位置の切り替えを行い、GIS における地理情報の基本操作を学ぶ。

\section{$3.2 「$ 形の複雑さを測る」}

形の複雑さを測るために、円形度(周長を面積の 平方根で除したもの、厳密には面積を $4 \pi$ 倍した ものを周長の二乗で除したものとして定義される ことが多い)を利用する。基本的な図形における值 を解析的に求めたものを説明した後に、演習に移 る。あらかじめ、図形を入力するとこの指標の值 をラベル表示するように教材を準備しており、学 生に様々な形を入力させ、図形と円形度の関係、 この指標の限界などを学ばせる。次に、この值を 基にレンジごとに図形を塗り分け、またこの值を 高さとして図形を立ち上げるなどの主題図の作成 を行う(図 2 参照)。

さらに、同様の作業を大阪市の 24 区の行政界の 情報を使って行う。基本図形の場合は、教員側で 作りこんだ教材を利用したが、大阪市の行政界の 演習の場合は、手を加えていない行政界の情報を 配布し、円形度を式として登録する、属性值をラ ベル表示する主題図を作成する、といった一連の

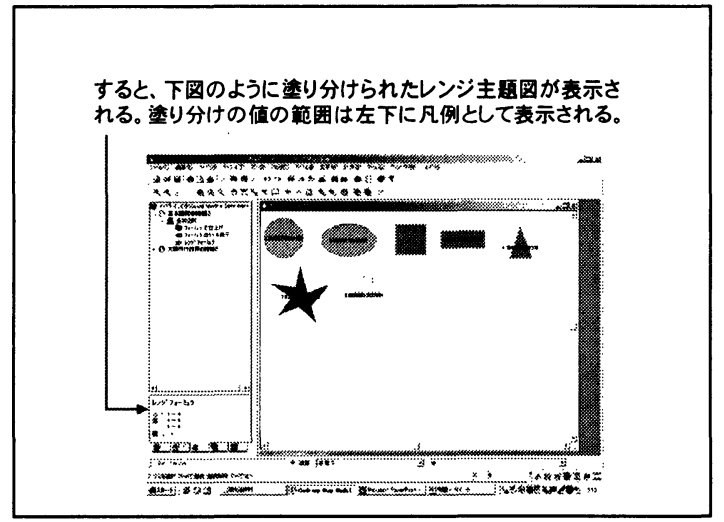

図 2 様々な形の入力と複雑さの值の表示(教材より)

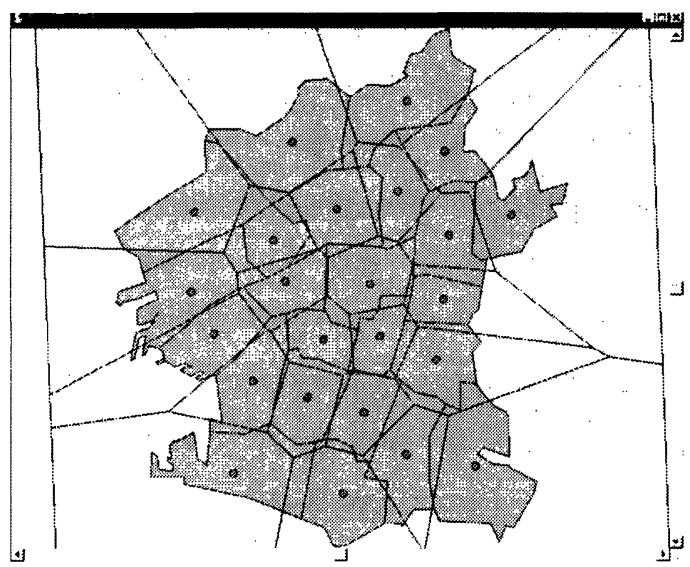

図 3 区の重心によるボロノイ図と行政界の重ね合わせ

作業まで含めてすべて学生が自ら行う。最後に、 大阪市の中でこの指標の值が大きい(円形ではな い)形状の区がどのあたりに存在するかを調べる。

$3.3 「$ 点の分布及び線分によるネットワークの特性 を測る」

点の分布の特性の把握のため、点の分布を基に ボロノイ図を作成し、ボロノイ多角形の面積のば らつきを見る。また、線分によるネットワークの 特性を把握するため、最短経路検索を行う。講義 では、ボロノイ図の概念、なぜボロノイ図を利用 するか、最短経路の位置などについて説明を行う。 演習では、まずあらかじめ 3 種類の点の分布を基 にボロノイ図まで作成しておいたものを配布し、 レイヤーの切り替えによりそれぞれのボロノイ図 を表示させ、ボロノイ多角形の面積の散らばりを 確認させる。次に、大阪市 24 区の行政界の教材を 配布し、区の重心位置を点の分布と考えてボロノ イ図を作成し、これと実際の行政界の重ね合わせ を行う(図 3 参照)。 
最短経路検索については、まず放射環状と格子 状のネットワークについて検索を行い、特に放射 環状の場合について始点と終点の取り方によって 経路がどのように変化するか確認させる。さらに、 大阪市の道路網のデータを用い、同様の検索を行 う。

これら 3 コマの演習において、出席した学生は 全員課題を所定のレベルまで達成することができ、 授業終了時に教材(演習の結果を含むもの)を回収 することができた。

\section{4. 授業調査の結果}

本科目の学期末試験の場において、授業調査を 行った。調査は、表 1 に示した 12 回の授業(第 9 回は中間試験で除く)を対象とし、面白いかったか、 分かりやすかったか、役に立つと思うか、人に勧 めたいと思うか、の 4 項目について「強くそう思 う」から「全くそう思わない」まで 5 段階で回答 させた。また、特に GIS を用いた 3 回の授業と全 体についてそれぞれ自由記述でコメントを求めた。

図 4 は、各授業ごとの回答の平均值(「強くそう 思う」を 5 点とする)を示したものである。表の通 り、GIS を用いた 3 回については、それ以外に比 ベて評価が低かった。自由記述の結果によれば、 コンピュータを用いた演習は興味深かったものの、 マニュアル通りに急いで作業を進めるだけなので、 面白くないというものや、学んだことが何の役に 立つのか分からない、といつたことが原因になっ ているようであった。全体に対する自由記述の評 価は高かった。また図 5 は、各学科ごとに回答を 分け、さらに GIS を用いた 3 回と用いていない 9 回に分けてそれぞれの平均值を求めた上で、GIS を用いた回の平均值をそれ以外の平均值で除した ものを示したものである。すなわち、值が 1 を超 えていれば GIS を用いた授業を肯定的に評価して いることになる。この図によれば、特に建築学科 と居住環境学科が GIS を用いた授業を低く評価し ており、それ以外はほぼ同様に評価していること が分かる。

今後は、スケジュールの調整により、もう少し 履修者が自由に操作を行う時間を増やすと共に、 身近な例を取り上げてこれらの図形解析が役に立

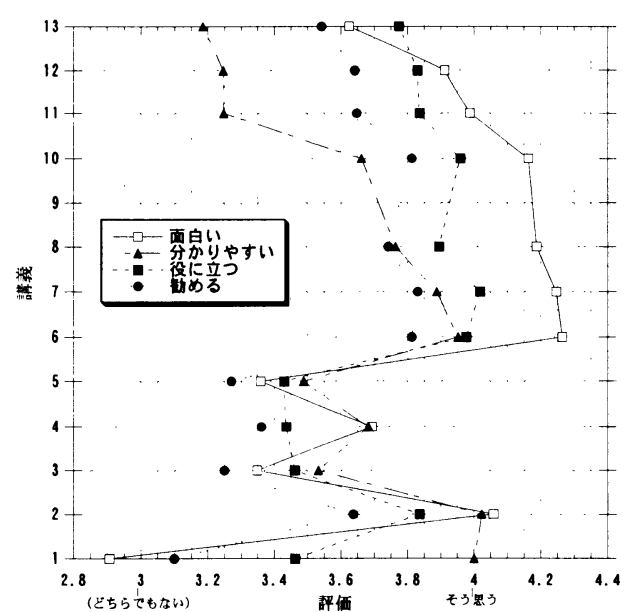

図 4 授業調查結果 設問ことの全員の平均値

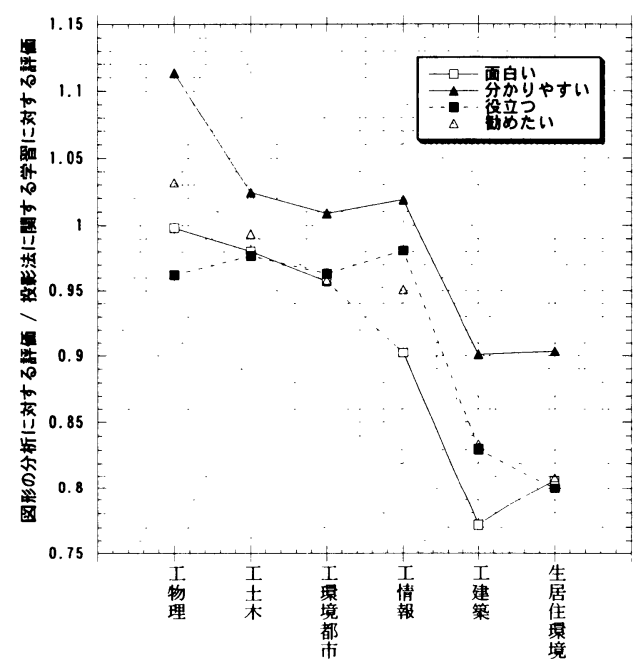

図 5 学科別 GIS 利用の授業の平均値をそれ以外 の授業の平均著で除したもの

つ事例を講義の中で分かりやす説明することを検 討している。また、特に GIS の授業に対して低い 評価を行った履修者の専門性も考慮して応用事例 の内容を検討したい。本科目は GIS のアプリケー ションの習得を目的としたものではないので、図 形解析に必要な機能は別途開発し、アプリケーシ ヨンに組み込んでいくような工夫も重要となろう。

\section{謝辞}

本稿で紹介した GIS 教材の開発については、学生に配布す るデータの作成において株式会社インフォマティクスの 協力を得た。また、本図形科学演習室の設備の導入に当た っては、大阪市立大学教務課課長代理の横田芳一氏、教務 課主查(当時)の増田實氏の協力を得た。ここに記して謝意 を表する。

\section{文献}

1) 鈴木広隆・三木信博(2002)「デザイン言語教授を目的とした 図形科学教育に関する一報告」日本建築学会技術報告集、第 16 号、pp.349-354、日本建築学会

2) 日本図学会編(1980)「図形科学ハンドブック」森北出版 